\title{
Analisis Pola Operasi Mempawah-Sanggau Kalimantan Barat
}

\author{
MUHAMMAD FAISHAL, SOFYAN TRIANA \\ Jurusan Teknik Sipil, Institut Teknologi Nasional, Bandung \\ Email: faishalibink83@gmail.com
}

\begin{abstract}
ABSTRAK
Moda transportasi kereta api mempunyai banyak keunggulan dibandingkan transportasi jalan antara lain kapasitas angkut besar (massal), cepat, aman, hemat energi, dan ramah lingkungan serta membutuhkan lahan yang relatif sedikit. Dalam studi kasus ini pembangunan jaringan jalur kereta api di Pulau Kalimantan khususnya jalur Mempawah-Sanggau adalah untuk memenuhi kebutuhan pergerakan penumpang dan pergerakan barang. Jalur Kereta Api MempawahSanggau direncanakan dengan satu jalur lintasan (single track) dengan panjang lintasan $\pm 237 \mathrm{~km}$. Dari studi terdahulu (studi kelayakan dan perencanaan jalan kereta api Pontianak-Sanggau, 2016) diketahui bahwa jumlah pergerakan penumpang pada Tahun 2060 sebesar 1.936.375 orang/tahun dan untuk jumlah pergerakan barang yang menggunakan moda transportasi kereta api pada Tahun 2060 sebesar 45.061 .558 ton/tahun. Untuk Tahun 2060 kapasitas lintas kereta api barang tertutup untuk jalur Mempawah-Sanggau tidak bisa dioperasikan sehingga perlu penambahan jalur.
\end{abstract}

Kata kunci: kereta api, pola operasi kereta api, Grafik Perjalanan Kereta Api (Gapeka).

\begin{abstract}
The railway transport have many adventages over road transportation among other large capacity, more fast, safe, energy saving and environmentally friendly and require less land. In this case study the construction of the railway network at Kalimantan Island especially track of Mempawah-Sanggau is to meet the needs of the movement of passengers and movement of item. The Mempawah-Sanggau railway is planned with a single track with length $\pm 237 \mathrm{~km}$. From previous studies (feasibility study and railway planning Pontianak-Sangggau, 2016) it is know thar the number of passenger movements in 2060 is 1.936 .375 person/year and the total of item movement using railway transport in 2060 is 45.061 .558 tons/year. For the year 2060 the capacity of trainway freight train for track at MempawahSanggau can not be operation and need for additional trainway.
\end{abstract}

Keywords: train, pattern of rail operations, Railway Travel Graph (RTG). 


\section{PENDAhUlUAN}

Awal studi dapat dikaitkan dengan jumlah permintaan akan transportasi di Pulau Kalimantan yang mengacu pada Rencana Induk Perkeretaapian Nasional Pulau Kalimantan Tahun 2011 dari studi terdahulu studi kelayakan dan trase pembangunan jalan kereta api antara PontianakSanggau Tahun 2016 bahwa prediksi jumlah pergerakan penumpang pengguna moda kereta api di Pulau Kalimantan pada Tahun 2060 adalah 1.936.375 orang/tahun dan untuk pergerakan barang pengguna moda kereta api pada Tahun 2060 adalah 45.061.558 ton/tahun.

Berkaitan dengan jumlah pergerakan di Pulau Kalimantan maka dilakukan studi yang salah satunya adalah studi pola operasi kereta api. Pola operasi kereta api Mempawah-Sanggau dengan panjang Track \pm 237 km, studi ini untuk mengetahui Grafik Perjalanan Kereta Api (Gapeka).

\section{MAKSUD DAN TUJUAN}

Untuk menganalisis pola operasi kereta api Mempawah-Sanggau sesuai spesifikasi dengan maksud untuk mengetahui kecepatan dan waktu tempuh, kapasitas lintas yang nantinya akan dijelaskan dalam grafik perjalanan kereta api (Gapeka).

\section{TINJAUAN PUSTAKA}

\subsection{Demand (Pergerakan)}

Demand (pergerakan) merupakan pola kegiatan tata guna lahan yang terdiri dari kegiatan interaksi manusia seperti sosial, ekonomi, kultur dan lain-lain. Kegiatan yang timbul dari sistem ini membutuhkan pergerakan sebagai alat pemenuhan kebutuhan yang perlu dilakukan setiap hari yang tidak dapat dipenuhi oleh tata guna lahan tersebut. Besarnya pergerakan sangat terkait dengan jenis dan intensitas kegiatan yang dilakukan menurut Atmaja (2015).

\subsection{Hambatan Sepanjang Alinyemen}

Dalam studi analisis pola operasi ini ada beberapa faktor jenis hambatan, diantaranya Hambatan Jalan $\left(H_{J}\right)$ terjadi selama kereta api bergerak, Hambatan Lengkung $\left(H_{L}\right)$ terjadi pada saat di lengkung, Hambatan Landai atau Lereng $\left(H_{s}\right)$ terjadi pada saat kereta api naik lereng.

\subsubsection{Hambatan Jalan $\left(H_{J}\right)$}

Hambatan Jalan terjadi akibat gesekan di dalam gandar, gesekan gelinding antara roda dan rel, gesekan udara atau angin, per satuan berat. Dalam menentukan hambatan jalan dapat dilihat pada Persamaan 1:

$$
H=a+C * V^{2}
$$

dengan:

$H_{j}=$ hambatan jalan [kg/ton],

$a=2,4$,

$C=\frac{1}{1000}$ (digunakan untuk kecepatan rendah sampai dengan kecepatan $80 \mathrm{~km} / \mathrm{jam}$ ),

$C=\frac{1}{1300}$ (digunakan untuk kecepatan tinggi diatas $80 \mathrm{~km} / \mathrm{jam}$ ). 


\subsubsection{Hambatan Lengkung $\left(H_{L}\right)$}

Hambatan landai atau lereng adalah hambatan yang terjadi karena kereta api bergerak naik lereng, bila kereta api menjalani sepur turun maka tidak ada Hambatan Lereng, hanya ada bila kereta api menjalani sepur naik dapat dihitung dengan Persamaan 2:

$$
H_{L}=\frac{375}{(R-50)}
$$

dengan:

$H_{L}=$ hambatan lengkung [kg/ton],

$R=$ jari-jari lengkung $[\mathrm{m}]$.

\subsubsection{Hambatan Landai atau Lereng $\left(H_{s}\right)$}

Hambatan landai atau lereng adalah hambatan yang terjadi karena kereta api bergerak naik lereng, bila kereta api menjalani sepur turun maka tidak ada Hambatan Lereng, hanya ada bila kereta api menjalani sepur naik, dapat dilihat pada Persamaan 3:

$$
H_{S}=S \mathrm{~kg} / \mathrm{ton}
$$

dengan $S$ adalah besaran kelandaian jalur tersebut.

Besar hambatan - hambatan yang terjadi tersebut dapat dikombinasikan dengan berat rangkaian dan kecepatan KA untuk mendapatkan daya traksi minimal yang dibutuhkan, seperti tertera pada Persamaan 4:

$$
N=1,1 * G *\left(H_{J}+H_{L}+\mathrm{H}_{S}\right) * \frac{V}{270}
$$

dengan:

$N \quad=$ daya traksi minimal [hp],

$G \quad=$ berat rangkaian [ton],

$V \quad=$ kecepatan $\mathrm{KA}[\mathrm{km} / \mathrm{jam}]$.

\subsection{Sarana Kereta Api}

Jenis sarana kereta api dalam studi ini dibagi dua yaitu:

a. Lokomotif dapat dilihat pada Gambar 1.

b. Kereta (untuk penumpang) dapat dilihat pada Gambar $\mathbf{2}$ dan gerbong (untuk barang) dapat dilihat pada Gambar 3, Gambar 4 dan Gambar 5.

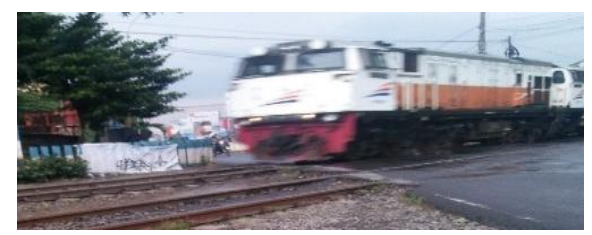

Gambar 1. Lokomotif CC 206

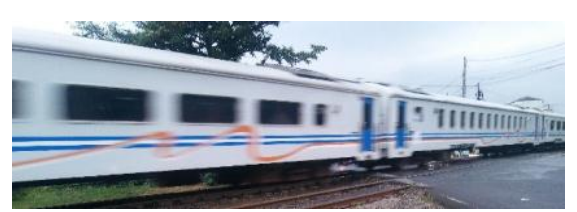

Gambar 2. Kereta penumpang 


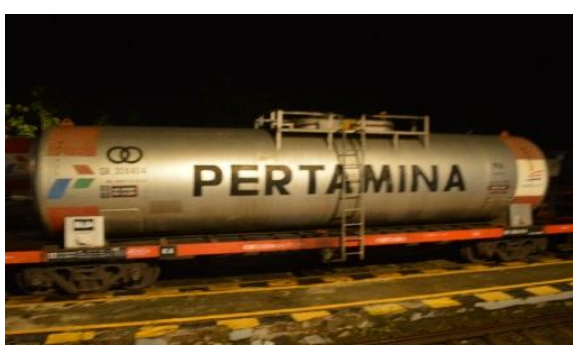

Gambar 3. Gerbong tangki (curah cair)

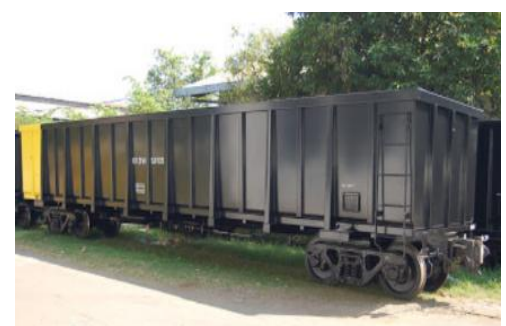

Gambar 4. Gerbong terbuka (curah padat)

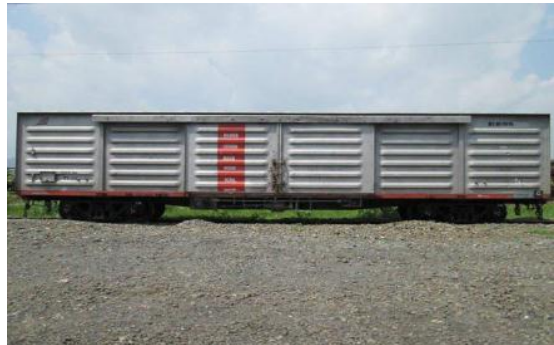

Gambar 5. Gerbong tertutup (Sumber: PT Munasa, 2016)

\subsection{Diagram Waktu-Ruang Perjalanan Kereta Api}

Diagram waktu-ruang pada praktek perkeretaapian di Indonesia disebut Gapeka (Grafik Perjalanan Kereta Api). Gapeka merupakan diagram waktu-ruang yang merupakan alat untuk menggambarkan variabel kendaraan (Kereta Api) yaitu jarak, headway, dan kecepatan kereta api dengan variabel arus (konsentrasi, arus dan kecepatan rata-rata). Gerakan setiap kereta api digambarkan sebagai grafik atau garis trayektori pada diagram tersebut. Untuk melihat contoh pergerakan kereta api waktu-ruang dapat dilihat pada Gambar 6.

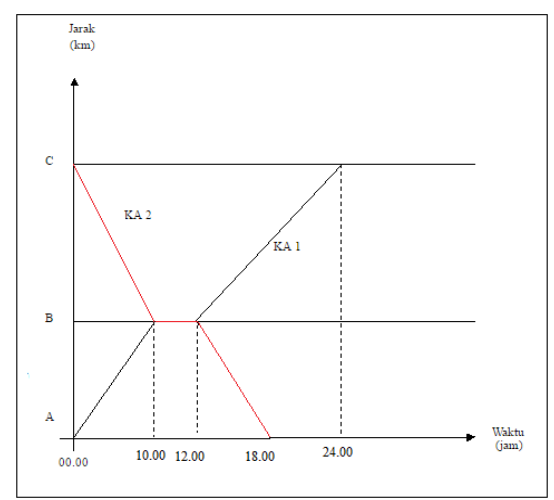

Gambar 6. Diagram pergerakan antara waktu dan ruang 


\subsection{Kecepatan Operasi}

Menurut Keputusan Menteri Perhubungan Tahun 2003 bahwa penetuan batas kecepatan operasi kereta api harus didasarkan:

a. Kelas jalur kereta api,

b. Kemampuan sarana kereta api (Lokomotif).

\section{ANALISIS DATA}

\subsection{Prosedur Penelitian}

Tugas Akhir ini dilakukan berawal dari identifikasi masalah dan penentuan topik pola operasi kereta api Pulau Kalimantan, kemudian mencari literatur-literatur yang berkaitan dengan pola operasi kereta api. jumlah pergerakan (demand) penumpang ataupun barang dari tahun 2024 sampai dengan Tahun 2060 dan rencana petak jalur kereta api yang menunjang studi kasus ini didapatkan dari studi terdahulu jalur Pontianak-Sanggau (PT. Munasa, 2016).

Jenis lokomotif dalam studi kasus ini diasumsikan menggunakan lokomotif seri CC 206 dapat dilihat pada Gambar 1, jenis kereta untuk penumpang dapat dilihat pada Gambar 2, sedangkan untuk kereta barang dibagi atas gerbong tangki (curah cair) dapat dilihat pada Gambar 3, gerbong terbuka (curah padat) dilihat pada Gambar 4 dan gerbong tertutup dapat dilihat pada Gambar $\mathbf{5}$.

Jumlah kereta api per rangkaian, sistem jalur, fasilitas operasi dan stasiun didapatkan dari studi terdahulu (jalur Pontianak-Sanggau, 2016). Jenis hambatan dalam studi ini dibagi atas Hambatan Jalan ( $\mathrm{Hj})$, Hambatan Lengkung ( $\mathrm{HI})$ dan Hambatan Lereng atau landai (Hs). Hambatan-Hambatan tersebut nantinya akan mempengaruhi Grafik Perjalanan Kereta Api (Gapeka).

\subsection{Analisis Data}

Dalam studi pola operasi Kereta api Mempawah-Sanggau data sekunder yang didapatkan dari studi terdahulu melanjutkan pengembangan dari perencanaan sarana dan prasarana perkeretaapian Pulau Kalimantan. Jumlah pergerakan penumpang dan barang telah dibahas pada pendahuluan, selanjutnya loading profile untuk Tahun 2024 sampai Tahun 2060. Untuk contoh perhitungan diambil Tahun 2024 dengan menggunakan kereta kereta penumpang dilihat Tabel 1 sampai dengan Tabel 4.

Tabel 1. Sarana Kebutuhan Kereta Api Tahun 2024

\begin{tabular}{ccccccc}
\hline No & Gerbong & Kapasitas & $\begin{array}{c}\text { Kebutuhan } \\
\text { Gerbong }\end{array}$ & Rangkaian & Lokomotif & $\begin{array}{c}\text { Jumlah } \\
\text { Gerbong } \\
\text { per Rangkaian }\end{array}$ \\
\hline 1 & Kereta Penumpang & 80 Orang & 8 & 1 & 1 & 8 \\
\hline 2 & Gerbong Barang: & - & - & - & - & 21 \\
\hline $2 \mathrm{a}$ & Gerbong Tertutup & 50 ton & 41 & 2 & 2 & 0 \\
\hline $2 \mathrm{~b}$ & $\begin{array}{c}\text { Gerbong Curah } \\
\text { Padat }\end{array}$ & 50 Ton & 0 & 0 & 0 & 13 \\
\hline $2 \mathrm{c}$ & $\begin{array}{c}\text { Gerbong Curah } \\
\text { Cair }\end{array}$ & 30 Kiloliter & 13 & 1 & 1 & 6 \\
\hline & Jumlah & 63 & 4 & 6 \\
\hline
\end{tabular}

(Sumber: PT Munasa, 2016) 
Tabel 2. Sarana Kebutuhan Kereta Api Tahun 2030

\begin{tabular}{ccccccc}
\hline No & Gerbong & Kapasitas & $\begin{array}{c}\text { Kebutuhan } \\
\text { Gerbong }\end{array}$ & Rangkaian & Lokomotif & $\begin{array}{c}\text { Jumlah } \\
\text { Gerbong } \\
\text { per Rangkaian }\end{array}$ \\
\hline 1 & Kereta Penumpang & 80 Orang & 9 & 1 & 1 & 9 \\
\hline 2 & Gerbong Barang: & - & - & - & - & 23 \\
\hline $2 \mathrm{a}$ & Gerbong Tertutup & 50 ton & 70 & 27 & 2 & 27 \\
\hline $2 \mathrm{~b}$ & $\begin{array}{c}\text { Gerbong Curah } \\
\text { Padat }\end{array}$ & 50 Ton & 27 & 2 & 2 & 26 \\
\hline $2 \mathrm{c}$ & $\begin{array}{c}\text { Gerbong Curah } \\
\text { Cair }\end{array}$ & 30 Kiloliter & 54 & 161 & 7 & 7 \\
\hline
\end{tabular}

(Sumber: PT Munasa, 2016)

Tabel 3. Sarana Kebutuhan Kereta Api Tahun 2045

\begin{tabular}{|c|c|c|c|c|c|c|}
\hline No & Gerbong & Kapasitas & $\begin{array}{l}\text { Kebutuhan } \\
\text { Gerbong }\end{array}$ & Rangkaian & Lokomotif & $\begin{array}{c}\text { Jumlah } \\
\text { Gerbong } \\
\text { per Rangkaian }\end{array}$ \\
\hline 1 & Kereta Penumpang & 80 Orang & 11 & 2 & 2 & 6 \\
\hline 2 & Gerbong Barang: & - & - & - & - & - \\
\hline $2 a$ & Gerbong Tertutup & 50 ton & 243 & 9 & 9 & 30 \\
\hline $2 b$ & $\begin{array}{c}\text { Gerbong Curah } \\
\text { Padat }\end{array}$ & 50 Ton & 27 & 1 & 1 & 26 \\
\hline $2 c$ & $\begin{array}{l}\text { Gerbong Curah } \\
\text { Cair }\end{array}$ & 30 Kiloliter & 96 & 3 & 3 & 30 \\
\hline & Jumlah & & 378 & 14 & 14 & \\
\hline
\end{tabular}

(Sumber: PT Munasa, 2016)

Tabel 4. Sarana Kebutuhan Kereta Api Tahun 2060

\begin{tabular}{|c|c|c|c|c|c|c|}
\hline No & Gerbong & Kapasitas & $\begin{array}{l}\text { Kebutuhan } \\
\text { Gerbong }\end{array}$ & Rangkaian & Lokomotif & $\begin{array}{c}\text { Jumlah } \\
\text { Gerbong } \\
\text { per Rangkaian }\end{array}$ \\
\hline 1 & Kereta Penumpang & 80 Orang & 12 & 2 & 2 & 7 \\
\hline 2 & Gerbong Barang: & - & - & - & - & - \\
\hline $2 a$ & Gerbong Tertutup & 50 ton & 782 & 27 & 27 & 30 \\
\hline $2 b$ & $\begin{array}{c}\text { Gerbong Curah } \\
\text { Padat }\end{array}$ & 50 Ton & 27 & 1 & 1 & 27 \\
\hline \multirow[t]{2}{*}{$2 c$} & $\begin{array}{c}\text { Gerbong Curah } \\
\text { Cair }\end{array}$ & 30 Kiloliter & 210 & 7 & 7 & 30 \\
\hline & Jumlah & & 1027 & 37 & 37 & \\
\hline
\end{tabular}

(Sumber: PT Munasa, 2016)

Dalam hal ini jenis perhitungan menggunakan contoh kereta penumpang pada tahun 2060 .

\subsection{Perhitungan Hambatan Traksi}

Asumsi berat setiap kereta adalah 40 ton, sedangkan lokomotif CC206 sendiri berbobot 90 ton, memiliki 6 gandar, dan berkekuatan $2250 \mathrm{hp}$. Kecepatan operasi kereta api direncanakan dengan kecepatan $80 \mathrm{~km} / \mathrm{jam}$. Berat total kereta api dapat dihitung dengan menggunakan persamaan $\mathrm{G}=$ berat lokomotif + (jumlah gerbong $\mathrm{x}$ berat setiap gerbong), kemudian menghitung hambatan traksi dengan memasukan Persamaan 1, Persamaan 2 dan Persamaan 3. Setalah mendapatkan jenis hambatan maka dapat dikombinasikan dengan berat rangkaian dan kecepatan kereta dengan menggunakan Persamaan 4. 


\subsection{Perhitungan Kapasitas Lintas}

Kapasitas lintas adalah banyaknya kereta api yang dapat dioprasikan pada suatu petak jalan per satuan waktu, untuk menghitung kapasitas lintas dapat menggunkan Persamaan 5:

$$
C=\frac{1440}{\mathrm{H}} * n
$$

dengan:

C

1440

$n$

$H$ [headway]
$=$ kapasitas lintas $[\mathrm{KA} /$ hari],

$=60 * 24$ [60 adalah jumlah menit dalam satu jam, 24 adalah jumlah jam dalam 1 hari],

$=0,6$ untuk jalur tunggal (PT. Dinamika Konsultan Mandiri, 2016),

$=\frac{60 * D+t^{\prime}}{v^{\prime}}$ (dimana $D$ adalah jarak, $t^{\prime}$ adalah sinyal blok mekanik CTC dengan nilai 0,75 dan $v^{\prime}$ adalah Kecepatan rata-rata. Satuan headway adalah menit).

\subsection{Menghitung Waktu Tempuh}

Dalam menghitung waktu tempuh tergantung jarak dan kecepatan, dalam waktu tempuh kecepatan yang digunakan adalah kecepatan rata-rata, untuk menghitung waktu tempuh dapat menggunakan Persamaan 6:

$$
t=\frac{s}{v^{\prime}}
$$

dengan:

$t \quad=$ waktu tempuh [menit],

$s \quad=$ jarak $[\mathrm{km}]$,

$v^{\prime} \quad=$ kecepatan rata-rata $[\mathrm{km} / \mathrm{jam}]$.

untuk menganalisis kapasitas lintas dan menganalisis waktu tempuh dapat menggunakan Persamaan 1 sampai dengan Persamaan 6.

setelah mendapatkan kecepatan aktual, kapasitas lintas dan waktu tempuh maka selanjutnya masukan ke dalam grafik perjalanan kereta api.

Untuk kereta curah padat Tahun 2024 tidak ada dan untuk kereta gerbong tertutup pada tahun 2060 kapasitasnya melebihi kapasitas lintas makatidak dimasukan ke dalam Gapeka. Grafik perjalanan kereta api dari Tahun 2024 sampai dengan Tahun 2060 dapat dilihat pada Gambar 7 sampai Gambar 10. 


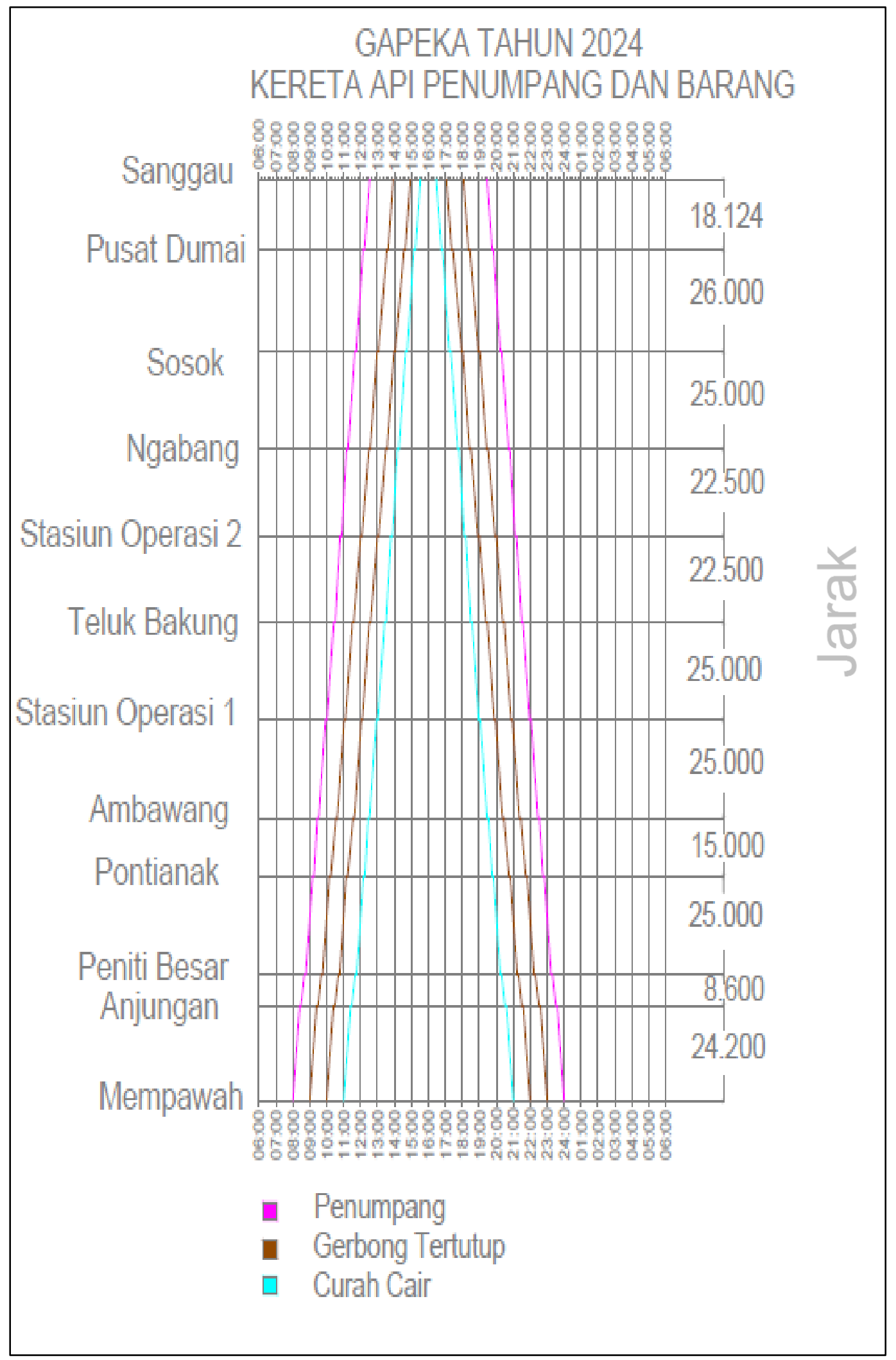

Gambar 7. Gapeka kereta penumpang dan barang tahun 2024 


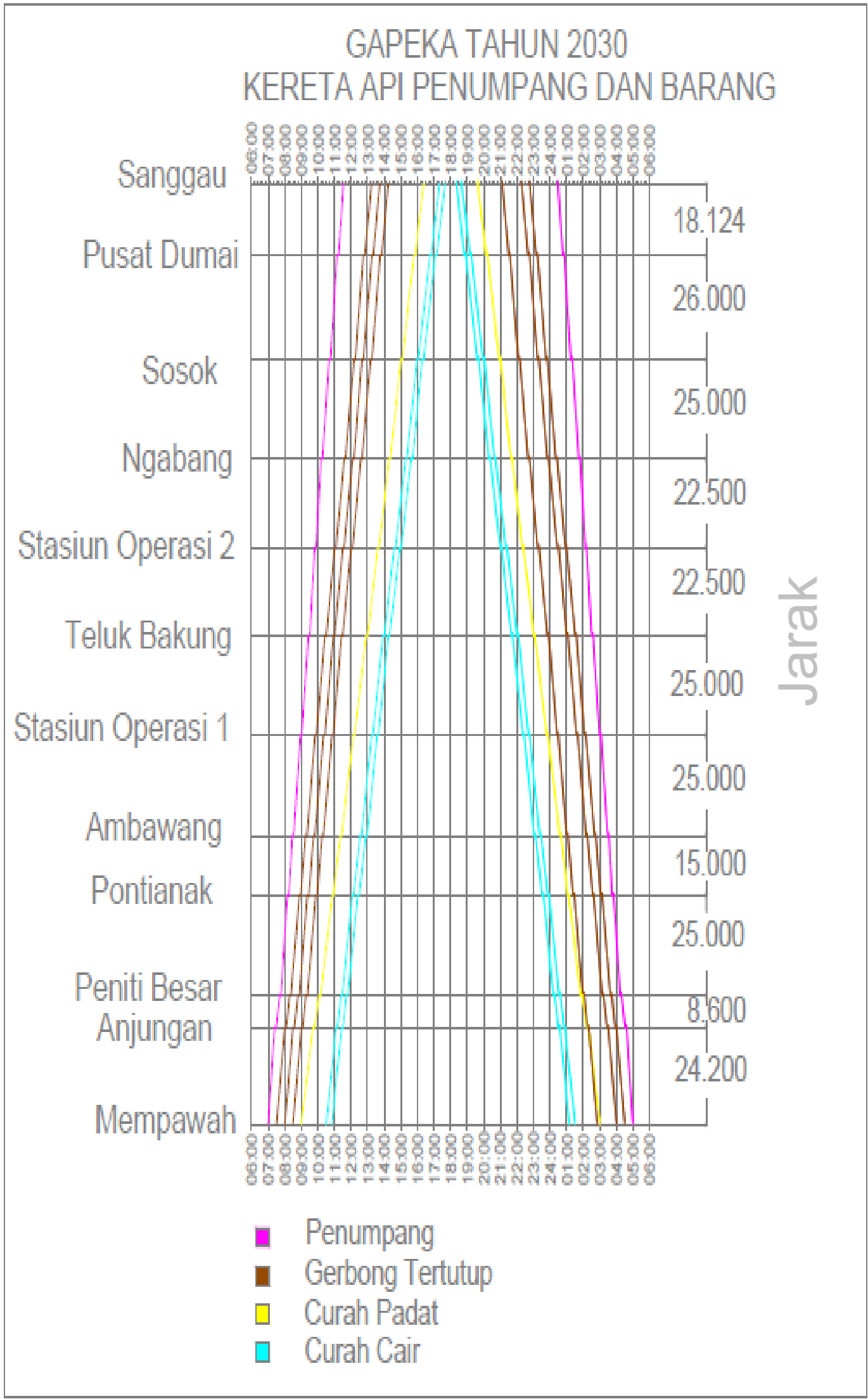

Gambar 8. Gapeka kereta penumpang dan barang tahun $\mathbf{2 0 3 0}$ 


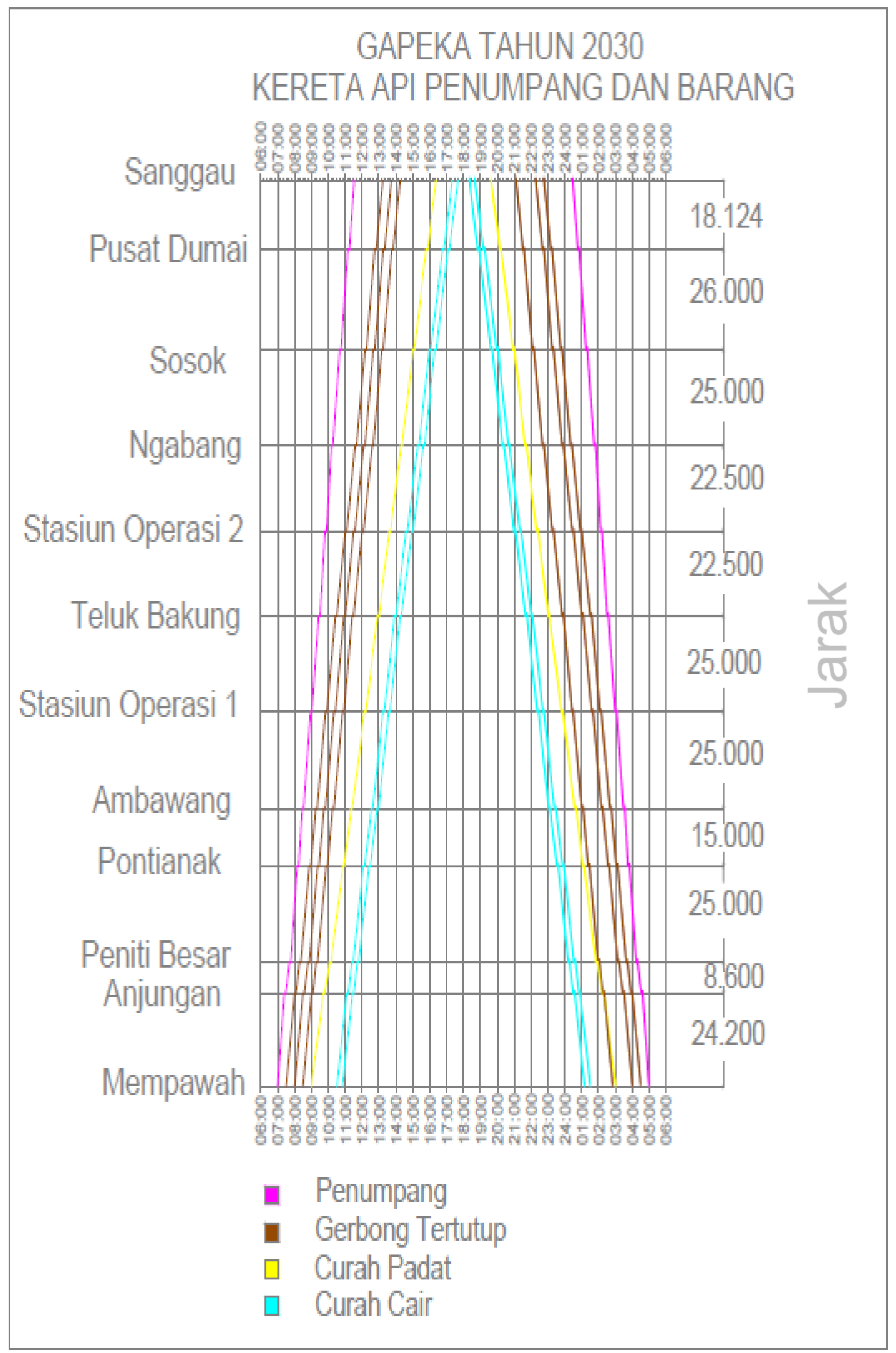

Gambar 9. Gapeka kereta penumpang dan barang tahun 2045 


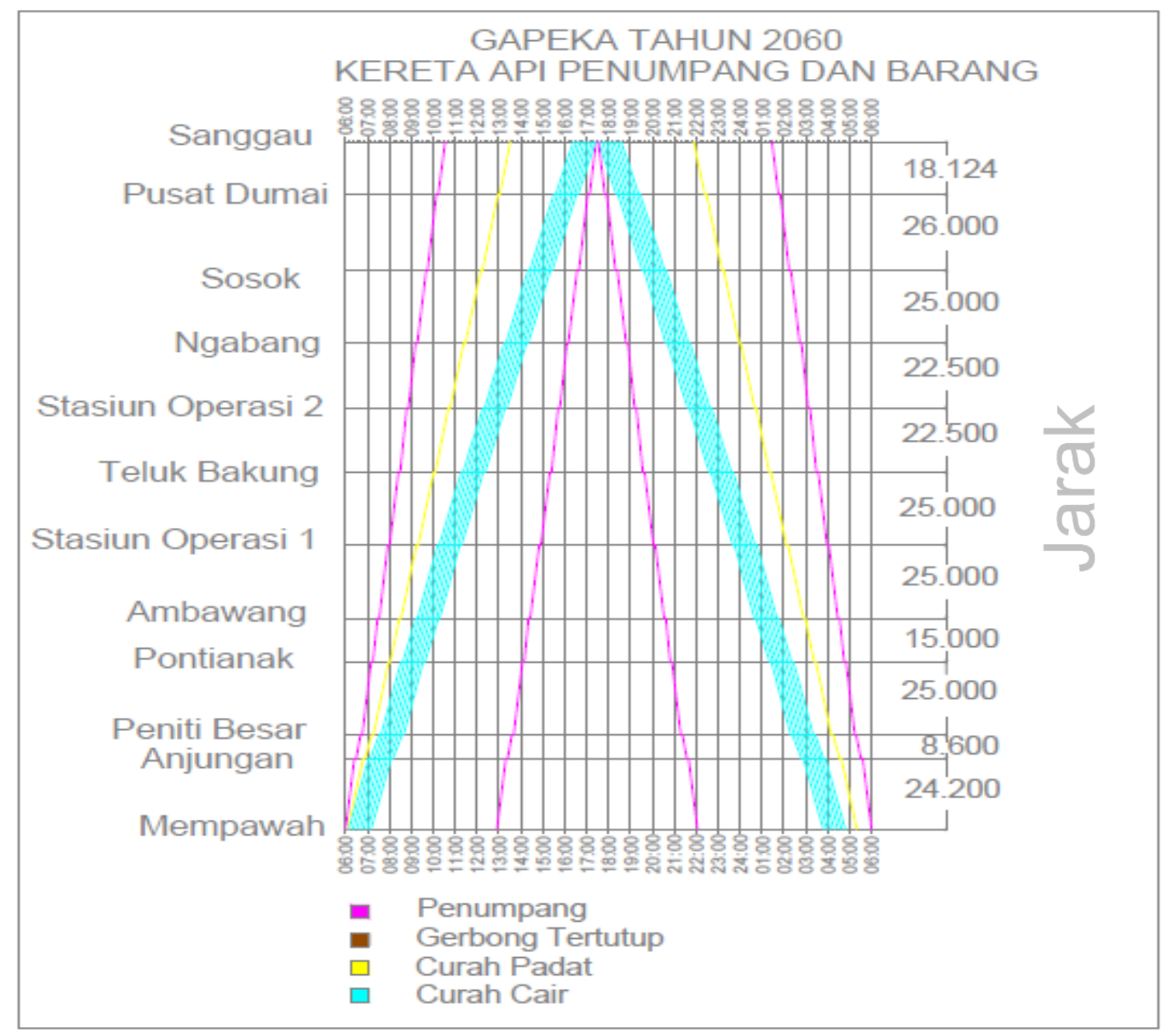

Gambar 10. Gapeka kereta penumpang dan barang tahun 2060

\section{KESIMPULAN}

Berdasarkan hasil analisis dapat ditarik kesimpulan bahwa setiap kecepatan dan waktu tempuh kereta api berbeda-beda tergantung jumlah rangkaian, jenis lokomotif, jenis dan jumlah gerbong. Pada tahun 2060 pola pergerakan kereta api pada jalur Mempawah-Sanggau padat, jumlah pergerakan barang jauh lebih besar dibandingkan jumlah pergerakan penumpang. Kapasitas lintas untuk kereta gerbong tertutup Tahun 2060 tidak bisa beroperasi karena melebihi kepasitas, sehingga diperlukan penambahan jalur kereta api (double track).

\section{DAFTAR RUJUKAN}

Atmaja, S. (2015). Rekayasa Jalan Kereta Api. Yogyakarta: LP3M-UMY.

Kementerian Perhubungan. (2003). Pengoperasian Kereta Api. Jakarta: Ditjen Perhubungan. Kementerian Perhubungan. (2011). Rencana Induk Perkeretaapian Nasional. Jakarta: Ditjen Perkeretaapian.

PT. Dinamika Konsultan Mandiri. (2016). DED Pembangunan Jalur Kereta Api Lintas TanjungTanah Grogot-Balikpapan. Bandung.

PT. Munasa. (2016). Analisis Pola Operasi Kereta Api Pontianak-Sanggau. Jakarta. 